\title{
ANALISIS TINDAK TUTUR ILOKUSI PADA PERCAKAPAN NABI MUSA AS. DALAM SURAT THAHA
}

\author{
Endah Kusumawati ${ }^{1}$, Nahdliyyatul Azimah ${ }^{2}$ \\ Universitas Negeri Malang, UIN Sunan Ampel Surabaya \\ E-mail: ${ }^{1} \underline{\text { end.ndha@gmail.com }},{ }^{2}$ zima_study@yahoo.co.id
}

Doi: $10.24252 /$ saa.v8i2.17559

\begin{abstract}
Abstrak
Surat Thaha atau Al-Kalim merupakan surat yang menjadi penghibur Rasulullah Saw. atas ujian dunia berupa ejekan kaum Quraisy terhadapnya dan memuat hikmah di dalamnya yang banyak menceritakan tentang kisah Nabi Musa as. Salah satu kisahnya adalah Allah swt. mengutusnya untuk mendatangi Firaun dan menyampaikan kebenaran tentang Tuhan dan seruan pada agama yang benar, hingga kisah mengenai kemarahannya terhadap Samiri. Dari ayat-ayat inilah, banyak terjadi percakapan Nabi Musa as. dengan berbagai mitra tuturnya yang dalam penelitian ini dianalisis dari segi tindak tutur ilokusi untuk mengetahui makna tersembunyi di setiap ujaran. Metode penelitian yang digunakan adalah metode kualitatifdeskriptif. Teknik pengumpulan data yang digunakan adalah dokumentasi dan observasi. Teknik analisis data yang digunakan adalah (1) mencatat tuturan Nabi Musa as., (2) mengumpulkan dan mengategorikan ujaran, (3) mendeskripsikan makna yang tersirat didukung dengan data sekunder. Hasil penelitian menunjukkan bahwa (1) ilokusi jenis asertif: menyatakan/memberikan informasi, memberitahukan, menegaskan, memutuskan, mengajukan pertanyaan, menyangkal, menyatakan, dan mengingkari, (2) ilokusi jenis deklaratif, berupa menunjuk dan membebaskan, (3) ilokusi jenis komisif: sumpah, menjanjikan, memanjatkan doa, dan menawarkan, (4) ilokusi jenis direktif: menasehati, memerintahkan, meminta, memperingatkan, memberi pesan, dan melarang, serta (5) ilokusi jenis ekspresif: menyapa, dan memanggil.
\end{abstract}

Kata Kunci: Tindak Tutur Ilokusi; Percakapan Nabi Musa as.; Surat Thaha

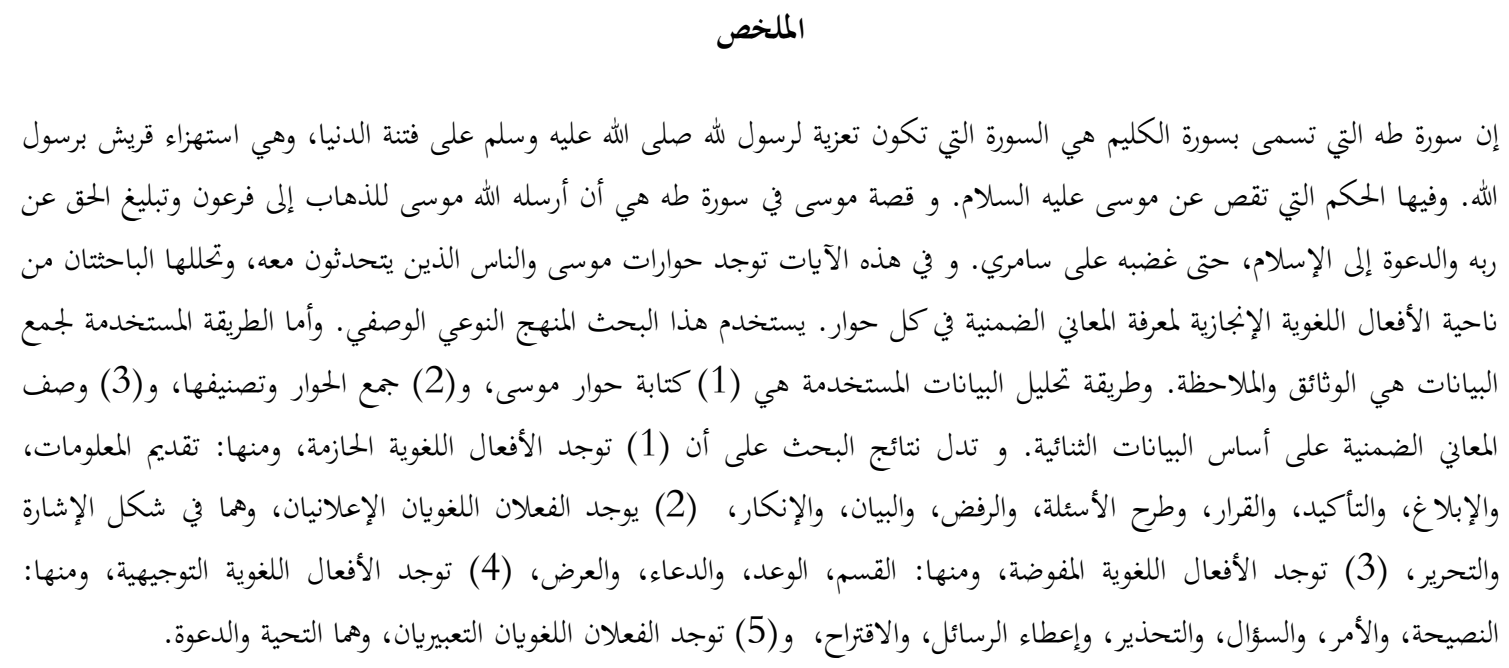


الكلمات الرئيسية: الأفعال اللغوية الإنجازية، حوار موسى، سورة طه.

\section{PENDAHULUAN}

Sejak 15 abad silam Al-Quran telah diturunkan ${ }^{1}$ oleh Allah swt. kepada Muhammad saw, melalui perantara Jibril. Al-Quran sebagai kitab suci umat Islam yang statusnya amat sakral bagi pengikutnya. Di samping itu, Al-Quran juga memiliki nilai khazanah keilmuan yang amat luas. Oleh karena itu, sejak dahulu sampai sekarang animo para sarjana muslim maupun non-muslim tidak pernah surut untuk mengkajinya dari berbagai aspek disiplin keilmuan yang berkembang.

Bahasa Arab merupakan bahasa fundamental yang digunakan oleh Allah swt. dalam menyampaikan segala pesannya di dalam Al-Quran. Bahasa Al-Quran ini memiliki keistimewaan lebih banyak dibanding dengan bahasa lainnya, seperti aspek sastranya yang tinggi dan keindahan retorikanya. Bahkan Umar bin Khattā $b^{2}$ berpesan kepada umat Islam untuk mempelajari bahasa Arab agar menambah kewibawaan dan ketajaman nalar. Jika kita mengamati bahasa Al-Quran, maka banyak terdapat sumber keilmuan di dalamnya yang dapat dikaji dan tidak hanya melihat dari sisi internal bahasa saja, namun dari sisi ekternal bahasa, yaitu pragmatik.

Pragmatik adalah suatu telaah umum mengenai bagaimana caranya konteks mempengaruhi peserta tutur dalam menafsirkan kalimat atau menelaah makna dalam kaitannya dengan situasi ujaran. Menurut Ainin $^{3}$ pragmatik merupakan salah satu cabang linguistik yang mengkaji makna suatu ujaran melalui pemahaman konteks yang menyertai ujaran tersebut. Jadi, penafsiran suatu ujaran atau wacana diperlukan pemahaman antar penutur dan mitra tutur, diikuti dengan situasi dan kondisi wacana atau ujaran tersebut dihasilkan. Konteks merupakan pijakan utama dalam analisis pragmatik, karena makna yang dihasilkan sangat terikat dengan konteks. Maka, bisa dikatakan bahwa dalam menganalisis wacana cenderung menggunakan pendekatan pragmatis. Brown and Yule ${ }^{4}$ (1988: 27) menyatakan dalam bukunya Discourse Analysis sebagai berikut:

"We emphasized that the discourse analyst necessarily takes a pragmatic approach to the study of language in use."

Bahwa menganalisis wacana perlu menggunakan pendekatan pragmatik dalam mengkaji pemakaian bahasa, dalam artian penganalisis wacana harus memahami konteks yang telah dijelaskan di atas.

Di samping itu, pragmatik, selain terkait dengan konteks, memiliki dasar kajian yang bermacam-macam, salah satunya adalah teori tindak tutur (speech act). Austin ${ }^{5}$ membedakan

${ }^{1}$ Ibrahim Muhammad, The Miracle of Seven: Akurasi Angka Matematis Al-Quran (Jakarta: Quanta, 2012), pengantar.

${ }^{2}$ Emǐl Badū' Ya'qūb, Fiqhu Al-Lughah Al-'Arabiyyah wa Khashāishuhā (Beirut: Dār Al-Tsaqāfah AlIslāmiyyah), h.37-38.

${ }^{3}$ Moh Ainin, Fenomena Pragmatik dalam al-Quran: Studi Kasus terhadap Pertanyaan (Malang: Misykat, 2010) h.33.

${ }^{4}$ Brown, Gillian, Yule, George. Discourse Analysis (Cambridge: The Press Syndicate of the University of Cambridge, 1988) h. 27.

5 J.L. Austin. Howto Do Things with Words (London: Oxford University Press, Amen House, 1962) hal. $102-103$ 
tindak bahasa menjadi tiga kategori, yaitu tindak lokusi, tindak ilokusi, dan tindak perlokusi. Tindak lokusi merupakan tindak mengucapkan ujaran dengan makna sebagaimana terdapat dalam ujaran. Tindak ilokusi merupakan tindak melakukan sesuatu. Tindak perlokusi merupakan efek yang ditimbulkan oleh ujaran yang disampaikan oleh penutur. Searle (dalam Rahardi ${ }^{6}$ ) juga mengemukakan ada tiga macam tindak tutur, antara lain: lokusioner, ilokusioner, dan perlokusi.

Di antara jenis-jenis tindak tutur ini, tindak tutur ilokusi adalah tindak tutur yang memiliki makna tersembunyi di balik sebuah ujaran dalam percakapan, apa yang sebenarnya dimaksud oleh penutur, dan mitra tutur dapat merespons atau melakukan tindakan setelah memahami maksud tersirat dari penutur. Searle (dalam Rahardi ${ }^{7}$ ) menyatakan bahwa ilokusioner merupakan tindak sesuatu dengan maksud dan fungsi tertentu pula. Ia membagi ilokusi menjadi lima jenis yang masing-masing memiliki fungsi komunikatif: asertif (menjelaskan bahwa proposisi yang disampaikan itu benar), direktif (tindak yang dimaksudkan agar pendengar melakukan suatu tindakan sebagaimana terdapat dalam ujaran), ekspresif (tindak yang dilakukan untuk mengekspreksikan perasaan kejiwaan penutur sehubungan dengan keadaan tertentu), komisif (tindak yang mengharuskan penutur untuk melakukan tindakan yang terdapat dalam ujaran), dan deklaratif (tindak yang menghubungkan isi proposisi dengan realitas sebenarnya).

Kelima jenis ilokusi ini menarik jika digunakan untuk menganalisis wacana yang dipilih dalam penelitian ini, yaitu salah satu dari ayat-ayat Alquran yang memiliki makna tersurat dan tersirat di dalamnya yang dapat digali secara mendalam. Wacana yang dipilih dalam penelitian ini adalah Surat Thaha (ST) yang memiliki nama lain Al-Kalı̈m ${ }^{8}$ yakni mitra tutur, terdiri dari 135 ayat kesemuanya tergolong surat Makkiyah, yang mana diturunkan sebelum Rasulullah saw. hijrah ke Madinah. Nama Al-Kalǐm disematkan sebab banyaknya ayat dalam ST yang berkisah tentang Nabi Musa as..

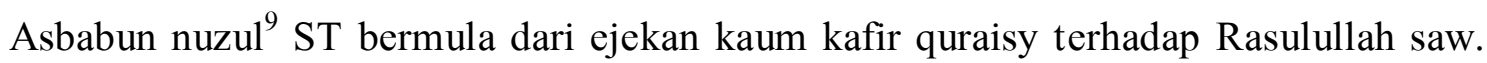
yang enggan mengikuti keyakinan paganisme. Bahkan, mereka mencela dengan lantang bahwa Al-Quran merupakan sumber kesengsaraan bagi beliau. Lalu, Allah swt. merespon peristiwa ini dengan menurunkan ST sebagai ta'ziyah atau hiburan untuk beliau agar tidak risau terhadap ujian dunia. Selain itu, ST memiliki nilai historis tersendiri di hati orang mukmin saat wasilah hidayah Islam datang kepada Umar bin Khattab bermula saat adik iparnya perempuan yang membacakan beberapa ayat dari ST. Tentunya, cerita ini sudah masyhur di kalangan umat Islam seantero dunia bahkan sudah lama bertebaran di kitab-kitab sirah nabawiyyah. Di samping itu, jika kita mengamati ST terdapat keindahan irama setiap akhir ayat berupa vokal A. Tentunya hal tersebut menambah cita rasa dalam tilawah dan tadabbur ST.

\footnotetext{
${ }^{6}$ R. Kunjana Rahardi, Pragmatik: Kesantunan Imperatif Bahasa Indonesia, (Jakarta: Erlangga, 2005), hal. 35-36.

${ }^{7}$ R. Kunjana Rahardi, Pragmatik: Kesantunan Imperatif Bahasa Indonesia, (Jakarta: Erlangga, 2005), hal. 36.

8 Quraish Shihab, Tafsir Al-Mishbah: Pesan, Kesan, dan Keserasian Al-Quran (Jakarta: Lentera Hati, Cetakan IV Volume.7 2011) h. 544.

${ }^{9}$ Imām Abĭ Al-Hasan 'Aliy bin Ahmad Al-Wāhidiy, Asbāb Nuzūl Al-Qurān (Beirut: Dār Al-Kutub AlIslāmiyyah, 2016) h. 312-313
} 
Kajian terdahulu yang menelaah ayat Al-Quran dari aspek pragmatik di antaranya: (1) Moh Mukhlas ${ }^{10}$ mengkaji "Fenomena Pragmatis dalam Al-Quran (Kajian atas Bentuk Imperatif pada Surat Al-Nur)". (2) Faiq Ainur Rofiq ${ }^{11}$ membahas "Analisa Redaksi Tindak Tut ur Imperatif dalam Surat Al-Baqarah". (3) Oka Putra Pratama ${ }^{12}$ menelaah "Tindak Tutur Santun dalam Kisah NabiYusuf". (4) Muhammad Sirotol Mustaqim ${ }^{13}$ menganalisis "Tinjauan Pragmatik Surat Al-Fatihah Terjemahan Indonesia Versi Departemen Agama". Berdasarkan kajian-kajian sebelumnya, penulis belum menemukan secara implisit fenomena pragmatis dari segi tindak tutur ilokusi yang berfokus pada percakapan Nabi Musa as. di ST. Oleh sebab itu, dalam kajian ini penulis menganalisis beberapa ayat dari ST yang mengandung tuturan Nabi Musa as. bersama mitra tuturnya yang variatif melalui salah satu teori wacana pendekatan pragmatis, yaitu teori tindak tutur ilokusi.

\section{METODE}

Penelitian ini bersandar pada metode kualitatif-deskriptif yang mana memiliki ciri penulis dan mitra penulis sebagai instrumen utama ${ }^{14}$ dalam mengumpulkan data primer maupun skunder. Data primernya berupa yaitu teks Al-Quran ST yang secara umum mengisahkan tentang Nabi Musa as. dan data skundernya berupa kitab, buku, jurnal, dan sumber-sumber lain yang relevan dengan topik yang dikaji. Pengumpulan data diperoleh melalui dokumentasi dan observasi.

Adapun teknik analisis data yang digunakan oleh penulis disitir dari (Seiddel:1998) ${ }^{15}$ yang meliputi: (1) mencatat tuturan Nabi Musa as. yang terdapat dalam surat Thaha dengan pemberian kode (penandaan) supaya datanya tetap dapat dilacak, (2) mengumpulkan segala bentuk tuturan Nabi Musa as. dalam ST, lalu setelah data terkumpul akan dipilah sesuai lingkup kajian wacana yang diinginkan dan membuat ringkasannya, (3) pada tahap terakhir ini penulis berupaya menyingkap makna dibalik tuturan wacana Nabi Musa as. dalam ST tersebut dan membuat temuan-temuan umum. Teknik keabsahan data yang digunakan dalam penelitian ini berdasarkan teori Bungin ${ }^{16}$, yaitu dengan melakukan ketekunan pengamatan, pengecekan melalui diskusi, kecukupan referensi, triangulasi teori dan antar-peneliti.

${ }^{10}$ Moh.Mukhlas, "Fenomena Pragmatis dalam Al-Quran (Kajian atas Bentuk Imperatif pada Surat AlNur)", Jurnal Al-Ta'dib Vol.9, No. 1, Juni (2019): hal. 49.

11 Faiq Ainur Rofiq, “Analisa Redaksi Tindak Tutur Imperatif dalam Surat Al-Baqarah”, Jurnal Kodifikasia Vol. 9, No.1 (2015): hal. 243.

${ }^{12}$ Oka Putra Pratama, "Tindak Tutur Santun dalam Kisah NabiYusuf", Arabiyat: Jurnal Pendidikan Bahasa Arab dan Kebahasaaraban Vol.4, No,2, Desember (2017): hal. 227.

${ }^{13}$ Muhammad Sirotol Mustaqim, "Tinjauan Pragmatik Surat Al-Fatihah Terjemahan Indonesia Versi Departemen Agama”. Skripsi (2014) Universitas Negeri Yogyakarta, hal. Xiii.

${ }^{14}$ Lexy J.Moleong, Metodologi Penelitian Kualitatif (Bandung: PT Remaja Rosda Karya Bandung, Cet32 2014), h.9.

${ }^{15}$ Lexy J.Moleong, Metodologi Penelitian Kualitatif (Bandung: PT Remaja Rosda Karya Bandung, Cet32 2014), h.248.

${ }^{16}$ Bungin, Burhan, Analisis Data Penelitian Kualitatif, (Jakarta: Raja Grafindo Persada, 2008) h. 254. 


\section{HASIL DAN PEMBAHASAN}

ST memuat alur komunikasi yang terjadi antara Nabi Musa as. dengan pengikutnya/keluarganya, Nabi Musa as. dengan Allah swt., Allah swt. dengan Nabi Musa as., dan Nabi Harun as., Nabi Musa as. dengan Nabi Harun as., Nabi Musa as. dengan Firaun, Nabi Musa as. dengan para ahli sihir, dan Nabi Musa as. dengan Samiri yang dalam sub bab ini akan dipetakan beserta analisis tindak tuturnya.

\section{Dialog Nabi Musa as. dengan Keluarganya}

\begin{tabular}{|l|l|l|}
\hline Ayat & Al-Quran Tarjamah Tafsiriyah" & \multicolumn{1}{c|}{ Analisis } \\
\hline 10 & Ketika Musa melihat api, ia berkata & Tindak tutur yang terdapat dalam dialog \\
& kepada pengikutnya: "Tinggallah & ini adalah ilokusi jenis asertif berupa \\
& kalian di sini. Sungguh aku melihat & "memberitahukan". Korpus data dalam \\
& api. Mudah-mudahan aku dapat & ayat 10 memiliki makna "Musa meminta \\
& kembali kepada kalian dari tempat & kepada keluarganya untuk tinggal \\
& itu dengan membawa sebagian api & sementara di tempat tertentu dan dia \\
& itu, atau aku akan mendapat & akan pergi untuk melihat api". Shihab \\
& petunjuk di tempat api itu." & menuturkan, 18 kata Inna memiliki \\
& & indikasi bahwa hanya Musa yang melihat \\
& & \\
\hline
\end{tabular}

Dialog Allah swt. dengan Nabi Musa as.

\begin{tabular}{|l|l|l|}
\hline Ayat & Al-Quran Tarjamah Tafsiriyah" & \multicolumn{1}{c|}{ Analisis } \\
\hline 11. & $\begin{array}{l}\text { Tatkala Musa datang ke tempat api } \\
\text { itu, kami panggil dia: "wahai } \\
\text { Musa". }\end{array}$ & $\begin{array}{l}\text { Tindak tutur yang terdapat dalam dialog } \\
\text { ini adalah ilokusi jenis ekspresif berupa } \\
\text { "memanggil". Korpus data dalam ayat 11 } \\
\text { memiliki makna Allah memanggil Musa } \\
\text { agar segera menghadap kepada-Nya. } \\
\text { Menurut Sayyid Quthub panggilan atau } \\
\text { sapaan Allah kepada Musa tidak bisa } \\
\text { dideskripsikan secara nyata, sebab hal } \\
\text { tersebut di luar nalar manusia. }\end{array}$ \\
\hline 12. & $\begin{array}{l}\text { "Sungguh Aku adalah Tuhanmu. } \\
\text { Oleh karena itu lepaskanlah kedua } \\
\text { sandalmu. Sungguh kamu berada" } \\
\text { dalam di lembah yang suci, Thuwa". }\end{array}$ & $\begin{array}{l}\text { Tindak tutur yang terdapat dalam dialog } \\
\text { ini adalah ilokusi jenis asertif berupa } \\
\text { "pernyataan informasi". Korpus data } \\
\text { dalam ayat 12 memiliki makna Allah } \\
\text { memanggil Musa untuk memberitahukan } \\
\text { dengan tegas bahwa Dia adalah Tuhan- } \\
\text { Nya, di samping itu Allah meminta Musa } \\
\text { untuk melepaskan terompahnya-sebab dia }\end{array}$ \\
\hline
\end{tabular}

${ }^{17}$ Muhammad Thalib, Al-Quranul Karim: Tarjamah Tafsiriyah, (Solo: CV Qolam Mas, 2012) h. 249

${ }^{18}$ M. Quraish Shihah, Tafsir Al-Misbah: Pesan, Kesan, dan Keserasian Al-Quran...h. 563.

${ }^{19}$ Muhammad Thalib, Al-Quranul Karim: Tarjamah Tafsiriyah, (Solo: CV Qolam Mas, 2012) h. 249-250

${ }^{20}$ M. Quraish Shihah, Tafsir Al-Misbah: Pesan, Kesan, dan Keserasian Al-Quran Volume 7 (Jakarta: Lentera Hati Cetakan IV, 2011) h. 565. 


\begin{tabular}{|c|c|c|}
\hline & & $\begin{array}{l}\text { berada di lembah yang suci. Kalimat ini } \\
\text { termasuk dalam ilokusi jenis direktif: } \\
\text { memerintahkan. Maksud dari kata thuwa } \\
\text { adalah lembah tempat Musa mendapat } \\
\text { wahyu dari Allah }{ }^{21} \text {. }\end{array}$ \\
\hline 13. & $\begin{array}{l}\text { "Wahai Musa, sungguh Aku } \\
\text { memilihmu menjadi utusan-Ku. } \\
\text { Oleh karena itu, dengarkanlah apa } \\
\text { yang diwahyukan kepadamu". }\end{array}$ & $\begin{array}{l}\text { Tindak tutur yang terdapat dalam dialog } \\
\text { ini adalah ilokusi jenis deklaratif dan } \\
\text { direktif berupa "menunjuk/mengangkat } \\
\text { dan meminta". Korpus data dalam ayat } 13 \\
\text { memiliki makna Allah secara tegas } \\
\text { memilih/menunjuk Musa sebagai rasul, } \\
\text { serta menerima wahyu pertama tanpa } \\
\text { medium malaikat. }{ }^{22} \text { Selain itu, Musa } \\
\text { diminta Allah untuk menyampaikan } \\
\text { risalah tersebut kepada umatnya. }\end{array}$ \\
\hline 14. & $\begin{array}{l}\text { "Sungguh Akulah Allah, tiada } \\
\text { Tuhan kecuali Aku. Oleh karena itu, } \\
\text { taatlah kepada-Ku r dan } \\
\text { laksanakanlah shalat r untuk } \\
\text { mengingat-Ku". }\end{array}$ & $\begin{array}{l}\text { Tindak tutur yang terdapat dalam dialog } \\
\text { ini adalah ilokusi jenis asertif berupa } \\
\text { "memberitahu" dan "menegaskan" bahwa } \\
\text { sungguh Allah adalah Tuhan yang Esa dan } \\
\text { tidak ada Tuhan selain-Nya, serta supaya } \\
\text { para mukallaf mengetahui hal ini, } \\
\text { sekaligus menjadi kewajiban pertama yang } \\
\text { dilimpahkan kepada mereka. }{ }^{23} \text { Selain itu } \\
\text { terdapat jenis direktif berupa } \\
\text { "memerintahkan". Dia menandaskan } \\
\text { kepada Musa sebagai konsekuensi beriman } \\
\text { kepada Allah adalah melaksanakan segala } \\
\text { perintahnya-salah satunya salat. Salat } \\
\text { dalam konteks zaman Nabi Musa adalah } \\
\text { ritual doa dan ibadah wajib yang berbeda } \\
\text { dengan tata caranya dengan salat yang kita } \\
\text { kenal saat ini. Namun esensinya sama, } \\
\text { yaitu munajat kepada Allah. }\end{array}$ \\
\hline 15. & $\begin{array}{l}\text { "Sungguh kiamat itu pasti datang. } \\
\text { Nyaris Aku tidak merahasiakannya } \\
\text { kepadamu agar setiap orang } \\
\text { mengetahui bahwa pada hari kiamat } \\
\text { kelak, ia diberi balasan sesuai } \\
\text { amalnya". }\end{array}$ & $\begin{array}{l}\text { Tindak tutur yang terdapat dalam dialog } \\
\text { ini adalah ilokusi jenis asertif berupa } \\
\text { "memberitahukan" dan jenis komisif } \\
\text { berupa "menjanjikan". Korpus data dalam } \\
\text { ayat } 15 \text { memiliki makna bahwa Allah } \\
\text { secara tegas memberi informasi kepada } \\
\text { Musa bahwa hari kiamat pasti terjadi, dan } \\
\text { setiap manusia pasti mendapat balasan } \\
\text { sesuai dengan perbuatannya. Menurut } \\
\text { Sayyid Quthub" kehadiran Hari Kiamat }\end{array}$ \\
\hline
\end{tabular}

${ }^{21}$ M. Quraish Shihah, Tafsir Al-Misbah: Pesan, Kesan, dan Keserasian Al-Quran...h. 565-566.

${ }^{22}$ M. Quraish Shihah, Tafsir Al-Misbah: Pesan, Kesan, dan Keserasian Al-Quran...h. 567.

${ }^{23}$ Abdullah bin Muhammad bin Abdurrahman bin Ishaq Al-Sheikh (Peneliti/Pentahqiq). Tafsir Ibnu Katsir: Jilid 5, (Bogor: Pustaka Imam asy-Syafi' i, 2003), hal. 373

${ }^{24}$ M. Quraish Shihah, Tafsir Al-Misbah: Pesan, Kesan, dan Keserasian Al-Quran...h. 571. 


\begin{tabular}{|c|c|c|}
\hline & & $\begin{array}{l}\text { termasuk hal gaib yang berfungsi sebagai } \\
\text { benteng pertahanan manusia dari } \\
\text { kemaksiatan guna mempersiapkan diri } \\
\text { menghadapi hari tersebut dengan } \\
\text { rangkaian amal saleh. }\end{array}$ \\
\hline 16. & $\begin{array}{l}\text { "Wahai Musa, karena itu engkau } \\
\text { jangan tertipu oleh propaganda } \\
\text { kesesatan dari orang yang tidak } \\
\text { beriman kepada hari kiamat dan } \\
\text { mengikuti hawa nafsunya, sehingga } \\
\text { engkau menjadi celaka di akhirat." }\end{array}$ & $\begin{array}{l}\text { Tindak tutur yang terdapat dalam dialog } \\
\text { ini adalah ilokusi jenis direktif berupa } \\
\text { "menasehati". Korpus data dalam ayat } 16 \\
\text { memiliki makna bahwa Allah menasehati } \\
\text { Musa agar waspada terhadap propaganda } \\
\text { kesesatan dari kaum yang tidak beriman. }\end{array}$ \\
\hline 17. & $\begin{array}{l}\text { "Wahai Musa, apa yang engkau } \\
\text { pegang di tangan kananmu? }\end{array}$ & $\begin{array}{l}\text { Tindak tutur yang terdapat dalam dialog } \\
\text { ini adalah ilokusi jenis "ekspresif" berupa } \\
\text { menyapa dan "asertif" } \\
\text { memutuskan. Sebagian ahli tafsir } \\
\text { berpendapat bahwa firman Allah dalam } \\
\text { ayat ini bisa diartikan hanya sekadar } \\
\text { sapaan, dan sebagian yang lain } \\
\text { menyatakan ini merupakan keputusan atas } \\
\text { apa yang akan Allah perbuat dengan } \\
\text { tongkat Musa saat itu juga, yakni } \\
\text { mengubahnya menjadi ular. } \\
\text { Shihab pun menuturkan pertanyaan Allah } \\
\text { yang ditujukan kepada Musa adalah untuk } \\
\text { menyadarkannya bahwa yang dipegangnya } \\
\text { adalah sebuah tongkat kayu yang mana } \\
\text { dengan izin Allah bisa berubah menjadi } \\
\text { seekor ular. }\end{array}$ \\
\hline 18. & $\begin{array}{l}\text { Musa berkata: "Ini tongkatku ya } \\
\text { Allah. Tongkat ini aku gunakan } \\
\text { untuk bertekan, menebas daun untuk } \\
\text { memberi makan dombaku dan } \\
\text { kepentingan yang lain." }\end{array}$ & $\begin{array}{l}\text { Tindak tutur yang terdapat dalam dialog } \\
\text { ini adalah ilokusi jenis asertif berupa } \\
\text { "memberitahukan". Korpus data dalam } \\
\text { ayat } 18 \text { memiliki makna bahwa Musa } \\
\text { merespon pertanyaan Allah terkait barang } \\
\text { yang dipegangnya secara detail. Shihab } \\
\text { menambahkan maksud pertanyaan Allah } \\
\text { kepada Musa guna mengingatkan Musa } \\
\text { supaya menjalankan kehidupan secara } \\
\text { seimbang dalam aspek jasmani dan rohani. }\end{array}$ \\
\hline 19. & $\begin{array}{l}\text { Allah berfirman: "Wahai Musa, } \\
\text { lemparkanlah tongkat itu." }\end{array}$ & $\begin{array}{l}\text { Tindak tutur yang terdapat dalam dialog } \\
\text { ini adalah ilokusi jenis direktif berupa } \\
\text { "memerintahkan". Korpus data dalam ayat } \\
19 \text { memiliki makna bahwa Allah }\end{array}$ \\
\hline
\end{tabular}

${ }^{25}$ Abdullah bin Muhammad bin Abdurrahman bin Ishaq Al-Sheikh (Peneliti/Pentahqiq). Tafsir Ibnu Katsir: Jilid 5... h. 375.

${ }^{26}$ M. Quraish Shihah, Tafsir Al-Misbah: Pesan, Kesan, dan Keserasian Al-Quran...h. 573.

${ }^{27}$ M. Quraish Shihah, Tafsir Al-Misbah: Pesan, Kesan, dan Keserasian Al-Quran...h. 573-574. 


\begin{tabular}{|c|c|c|}
\hline & & $\begin{array}{l}\text { mememerintahkan Musa untuk melempar } \\
\text { tongkat tersebut ke tanah }{ }^{28} \text {. Korpus data } \\
\text { dalam ayat ini berkaitan dengan ayat } \\
\text { berikutnya (20) yang merupakan perlokasi, } \\
\text { bahwa "Musa pun melemparkannya. Tiba- } \\
\text { tiba tongkat tersebut berubah menjadi } \\
\text { seekor ular dan merayap dengan cepat". }\end{array}$ \\
\hline 21. & $\begin{array}{l}\text { "Allah berfirman: Ambillah ular itu } \\
\text { dan janganlah kamu takut. Aku akan } \\
\text { mengembalikan ular itu menjadi } \\
\text { tongkat seperti semula." }\end{array}$ & $\begin{array}{l}\text { Tindak tutur yang terdapat dalam dialog } \\
\text { ini adalah ilokusi jenis direktif berupa } \\
\text { "memerintahkan". Korpus data dalam ayat } \\
21 \text { memiliki makna instruksi Allah yang } \\
\text { ditujukan kepada Musa supaya mengambil } \\
\text { ular tersebut dan tidak takut. }\end{array}$ \\
\hline 22. & $\begin{array}{l}\text { "Masukkanlah telapak tanganmu ke } \\
\text { saku bagian dalam bajumu. Lalu } \\
\text { ketika telapak tanganmu kamu } \\
\text { keluarkan, telapak tanganmu akan } \\
\text { memancarkan cahaya putih bersih } \\
\text { tanpa noda. Kejadian ini sebagai } \\
\text { mukjizat lain bagi kenabianmu." }\end{array}$ & $\begin{array}{l}\text { Tindak tutur yang terdapat dalam dialog } \\
\text { ini adalah ilokusi jenis direktif berupa } \\
\text { "memerintahkan", dan jenis asertif berupa } \\
\text { "memberitahukan". Korpus data dalam } \\
\text { ayat } 22 \text { memiliki makna instruksi Allah } \\
\text { yang ditujukan kepada Musa supaya } \\
\text { meletakkan tangannya di ketiaknya, dan } \\
\text { akan memancarkan cahaya setelah } \\
\text { dikeluarkan. Hal ini merupakan } \\
\text { pemberitahuan mukjizat kenabian yang } \\
\text { lain dari Allah. Menurut Shihab } \\
\text { memasukkan telapak tangan dan } \\
\text { mengeluarkannya dari ketiak memiliki } \\
\text { dampak psikologis yang cukup rumit yang } \\
\text { menyertai Musa dalam proses tersebut. }\end{array}$ \\
\hline 23. & $\begin{array}{l}\text { "Wahai Musa, kami perlihatkan } \\
\text { mukjizat ini kepadamu di samping } \\
\text { mukjizat-mukjizat lain sebagai bukti } \\
\text { kekuasaan kami yang agung". }\end{array}$ & $\begin{array}{l}\text { Tindak tutur yang terdapat dalam dialog } \\
\text { ini adalah ilokusi jenis asertif berupa } \\
\text { "memberitahukan". Korpus data dalam } \\
\text { ayat } 23 \text { memiliki makna bahwa Allah } \\
\text { secara tegas memberi informasi kepada } \\
\text { Musa bahwa Dia adalah Tuhan yang Maha } \\
\text { Kuasa atas segala mukjizatNya. }\end{array}$ \\
\hline 24. & $\begin{array}{l}\text { "Wahai Musa, datanglah kamu } \\
\text { kepada Firaun. Sesungguhnya } \\
\text { Firaun adalah orang yang dhalim". }\end{array}$ & $\begin{array}{l}\text { Tindak tutur yang terdapat dalam dialog } \\
\text { ini adalah ilokusi jenis direktif berupa } \\
\text { "memerintahkan", dan asertif berupa } \\
\text { "memberitahukan". Korpus data dalam } \\
\text { ayat } 24 \text { memiliki makna agar Musa } \\
\text { menghadap kepada Firaun, dan Allah } \\
\text { mengatakan padanya bahwa Firaun adalah } \\
\text { penguasa yang dhalim. }\end{array}$ \\
\hline $25-$ & lapangkanlah & Tindak tutur yang terdapat dalam dialog \\
\hline
\end{tabular}

\footnotetext{
${ }^{28}$ M. Quraish Shihah, Tafsir Al-Misbah: Pesan, Kesan, dan Keserasian Al-Quran...h. 574.

${ }^{29}$ Muhammad Thalib, Al-Quranul Karim: Tarjamah Tafsiriyah,.....h. 250.

${ }^{30}$ M. Quraish Shihah, Tafsir Al-Misbah: Pesan, Kesan, dan Keserasian Al-Quran...h. 576.
} 


\begin{tabular}{|l|l|l|}
\hline 35 & dadaku untukku, mudahkanlah & ini adalah ilokusi jenis komisif berupa \\
& urusanku, hilangkan cedal dari & "memanjatkan doa". Korpus data dalam \\
lidahku supaya mereka dapat & ayat 25-35 memiliki makna permintaan \\
memahami omonganku, dan berilah & dan permohonan tulus Musa kepada Allah. \\
aku seorang pembantu dari & Shihab mengutarakan bahwa tugas \\
keluargaku sendiri yaitu Harun & kenabian yang diemban Musa amat berat, \\
(saudaraku), dan jadikanlah dia & sehingga segala keluh dan kesahnya \\
sebagai teman dalam urusanku & diutarakan pada Allah. \\
supaya kami selalu mengagungkan & \\
Engkau dan banyak mengingat-Mu. & \\
"Sungguh Engkau benar-benar & \\
selalu mengawasi kami".
\end{tabular}

Dialog Allah swt. dengan Nabi Musa as., dan Nabi Harun as.

\begin{tabular}{|c|c|c|}
\hline Ayat & Al-Quran Tarjamah Tafsiriyah ${ }^{32}$ & Analisis \\
\hline 42. & $\begin{array}{l}\text { "Wahai Musa, datanglah kamu dengan } \\
\text { saudaramu kepada Firaun dengan } \\
\text { menunjukkan mukjizat dari-Ku dan } \\
\text { janganlah kamu lupa untuk mengingat- } \\
\text { Ku." }\end{array}$ & $\begin{array}{l}\text { Tindak tutur yang terdapat dalam dialog } \\
\text { ini adalah ilokusi jenis direktif berupa } \\
\text { "memerintahkan". Korpus data dalam } \\
\text { ayat } 42 \text { memiliki makna "Allah } \\
\text { meminta Musa dan Harun untuk } \\
\text { menghadap Firaun guna menunjukkan } \\
\text { mukjizat-Nya dan senantiasa } \\
\text { mengingat-Nya". }\end{array}$ \\
\hline 43. & $\begin{array}{l}\text { "Datanglah kamu berdua kepada } \\
\text { Firaun, karena sesungguhnya Firaun } \\
\text { adalah orang yang dhalim". }\end{array}$ & $\begin{array}{l}\text { Tindak tutur yang terdapat dalam dialog } \\
\text { ini adalah ilokusi jenis direktif berupa } \\
\text { "memerintah" untuk pergi menghadap } \\
\text { Firaun, dan asertif berupa } \\
\text { "memberitahukan". Korpus data dalam } \\
\text { ayat } 43 \text { memiliki makna "Allah } \\
\text { menegaskan kepada Musa dan Harun } \\
\text { bahwa Firaun adalah orang yang } \\
\text { dhalim". Hal tersebut senada dengan } \\
\text { firman Allah pada Musa dalam ayat } 24 \text {. }\end{array}$ \\
\hline 44. & $\begin{array}{l}\text { "Lalu berkatalah kepada Firaun dengan } \\
\text { lemah lembut. Mudah-mudahan Firaun } \\
\text { mau menyadari kesalahan- } \\
\text { kesalahannya atau dia masuk Islam". }\end{array}$ & $\begin{array}{l}\text { Tindak tutur yang terdapat dalam dialog } \\
\text { ini adalah ilokusi jenis direktif berupa } \\
\text { "memberi pesan". Korpus data dalam } \\
\text { ayat } 44 \text { memiliki makna "Allah } \\
\text { meminta Musa dan Harun untuk } \\
\text { menyampaikan risalah ketuhanan } \\
\text { kepada Firaun dengan penuh } \\
\text { kelembutan. Makna "lemah lembut" } \\
\text { adalah 'ajaklah Firaun untuk beriman } \\
\text { kepada Allah dan ajaklah kepada jalan }\end{array}$ \\
\hline
\end{tabular}

\footnotetext{
${ }^{31}$ M. Quraish Shihah, Tafsir Al-Misbah: Pesan, Kesan, dan Keserasian Al-Quran...h. 577.

${ }^{32}$ Muhammad Thalib, Al-Quranul Karim: Tarjamah Tafsiriyah, (Solo: CV Qolam Mas, 2012) h. 246

${ }^{33}$ M. Quraish Shihah, Tafsir Al-Misbah: Pesan, Kesan, dan Keserasian Al-Quran...h. 593.
} 


\begin{tabular}{|c|c|c|}
\hline & & kebenaran'. \\
\hline 45. & $\begin{array}{l}\text { Musa dan Harun berkata: "Wahai } \\
\text { Tuhan kami, sesungguhnya kami takut } \\
\text { Firaun akan membunuh kami atau dia } \\
\text { menyakiti kami". }\end{array}$ & $\begin{array}{l}\text { Tindak tutur yang terdapat dalam dialog } \\
\text { ini adalah ilokusi jenis asertif berupa } \\
\text { "menyatakan". Korpus data dalam ayat } \\
45 \text { memiliki makna "Musa dan Harun } \\
\text { menyatakan perasaan kekhawatirannya } \\
\text { kepada Allah bahwa Firaun adalah orang } \\
\text { yang dhalim". Di antara contoh } \\
\text { kekejaman Firaun adalah" membunuh } \\
\text { bayi laki-laki dari kalangan Bani Israil } \\
\text { dan memperbudak kaum perempuan. }\end{array}$ \\
\hline 46. & $\begin{array}{l}\text { "Allah berfirman: "Wahai Musa dan } \\
\text { Harun, kalian jangan takut, janganlah } \\
\text { kamu takut. Sungguh Aku senantiasa } \\
\text { melindungi kamu berdua. Aku men- } \\
\text { dengarkan dan mengawasi kamu } \\
\text { berdua." }\end{array}$ & $\begin{array}{l}\text { Tindak tutur yang terdapat dalam dialog } \\
\text { ini adalah ilokusi jenis asertif berupa } \\
\text { "memberitahukan". Korpus data dalam } \\
\text { ayat } 46 \text { memiliki makna "Allah } \\
\text { menegaskan kepada Musa dan Harun } \\
\text { bahwa Dia adalah Maha Pelindung". } \\
\text { Shihab mengungkapkan }{ }^{35} \text { bahwa Allah } \\
\text { menjamin keselamatan Musa dan Harun, } \\
\text { serta tidak akan membiarkan Firaun } \\
\text { menyiksa atau mengalahkan mereka } \\
\text { berdua. Hal ini didukung oleh } \\
\text { pernyataan dalam Tafsir Ibnu Katsir" } \\
\text { bahwa 'Aku bersama kalian, mendengar } \\
\text { ucapan kalian dan ucapannya (Firaun), } \\
\text { serta melihat posisi kalian berdua dan } \\
\text { juga posisinya, dan 'Aku bersama kalian } \\
\text { dengan perlindungan, pertolongan, dan } \\
\text { pembelaan-Ku'. }\end{array}$ \\
\hline 47 & $\begin{array}{l}\text { "Wahai Musa dan Harun, datanglah } \\
\text { kamu kepada Firaun dan katakanlah: } \\
\text { "Sungguh kami adalah dua orang } \\
\text { utusan Tuhanmu. Karena itu, kami } \\
\text { minta engkau lepaskan Bani Israil } \\
\text { untuk meninggalkan Mesir bersama } \\
\text { kami. Janganlah kamu menyiksa Bani } \\
\text { Israil. Sunguh kami datang membawa } \\
\text { mukjizat kenabian dari Tuhanmu. } \\
\text { Selamat sejahteralah bagi orang-orang } \\
\text { yang mengkuti Islam, agama Allah. }\end{array}$ & $\begin{array}{l}\text { Tindak tutur yang terdapat dalam dialog } \\
\text { ini adalah ilokusi jenis direktif berupa } \\
\text { "memerintah", yakni penutur-dalam } \\
\text { hal ini, Allah meminta kepada Musa } \\
\text { dan Harun untuk menghadap serta } \\
\text { mengatakan kepada Firaun bahwa } \\
\text { mereka berdua adalah utusan Allah, dan } \\
\text { juga mengajak Firaun untuk beriman } \\
\text { dan patuh terhadap-Nya. Selain itu, } \\
\text { terdapat ilokusi jenis deklaratif berupa } \\
\text { "membebaskan" yang berarti Musa } \\
\text { meminta Firaun untuk membebaskan } \\
\text { Bani Israil agar mereka semua } \\
\text { menyembah Allah dan tidak } \\
\text { mempersekutukan-Nya }\end{array}$ \\
\hline
\end{tabular}

${ }^{34}$ M. Quraish Shihah, Tafsir Al-Misbah: Pesan, Kesan, dan Keserasian Al-Quran...h. 597.

${ }^{35}$ M. Quraish Shihah, Tafsir Al-Misbah: Pesan, Kesan, dan Keserasian Al-Quran...h. 596.

${ }^{36}$ Abdullah bin Muhammad bin Abdurrahman bin Ishaq Al-Sheikh (Peneliti/Pentahqiq). Tafsir Ibnu Katsir: Jilid 5... h. 385. 


\begin{tabular}{|l|l|l|}
\hline & $\begin{array}{l}\text { memerintah untuk tidak menyiksa } \\
\text { mereka seperti yang biasa dilakukan } \\
\text { oleh Firaun. }\end{array}$ \\
\hline
\end{tabular}

\section{Dialog Nabi Musa as. dengan Firaun}

\begin{tabular}{|c|c|c|}
\hline Ayat & Al-Quran Tarjamah Tafsiriyah ${ }^{38}$ & Analisis \\
\hline 48 & $\begin{array}{l}\text { "Sungguh kami telah diberi wahyu, } \\
\text { bahwa orang-orang } \\
\text { mendustakan dan menolak ajaran- } \\
\text { ajaran rasul akan mendapat siksa } \\
\text { yang berat." }\end{array}$ & $\begin{array}{l}\text { Tindak tutur yang terdapat dalam dialog } \\
\text { ini adalah ilokusi jenis komisif berupa } \\
\text { "menjanjikan", yakni penutur-dalam hal } \\
\text { ini, Musa-memberi pesan kepada mitra } \\
\text { tutur, yaitu Firaun. Korpus data dalam } \\
\text { ayat } 48 \text { memiliki makna orang yang } \\
\text { berpaling dari ajaran Rasul dan enggan } \\
\text { menerimanya akan mendapatkan siksa } \\
\text { yang pedih. }\end{array}$ \\
\hline 49. & $\begin{array}{l}\text { Firaun berkata: "Wahai Musa, } \\
\text { siapakah Tuhan kamu berdua?." }\end{array}$ & $\begin{array}{l}\text { Tindak tutur yang terdapat dalam dialog } \\
\text { ini adalah ilokusi aserfatif berupa } \\
\text { "mengingkari". Dalam tafsir Ibnu Katsir" } \\
\text { dinyatakan bahwa Firaun bertanya kepada } \\
\text { Nabi Musa dengan mengingkari sang } \\
\text { Pencipta, Rabb sekaligus Pemelihara dan } \\
\text { Pemilik segala sesuatu. Firaun tidak } \\
\text { mengenal Tuhan yang mengutus kedua } \\
\text { Nabi tersebut dan dia berasumsi bahwa } \\
\text { tidak Ilah lain untuk Nabi Musa dan } \\
\text { Harun kecuali dia seorang. Dari ayat } \\
\text { inilah, pertanyaan yang dilontarkan Firaun } \\
\text { bukanlah pertanyaan rasa ingin tahu } \\
\text { terhadap Tuhan Musa dan Harun akan } \\
\text { tetapi justrumengingkarinya. }\end{array}$ \\
\hline 50. & $\begin{array}{l}\text { Musa menjawab: "Tuhan kami } \\
\text { adalah Tuhan yang memberikan rizki } \\
\text { kepada seluruh makhluk ciptaan-Nya } \\
\text { dan memberi petunjuk untuk } \\
\text { menjalani kehidupannya dengan } \\
\text { benar." }\end{array}$ & $\begin{array}{l}\text { Tindak tutur yang terdapat dalam dialog } \\
\text { ini adalah ilokusi jenis asertif berupa } \\
\text { "memberitahukan" dan "menegaskan". } \\
\text { Korpus data dalam ayat } 50 \text { memiliki } \\
\text { makna "Musa menjawab dengan lugas } \\
\text { atas pertanyaan yang diajukan oleh } \\
\text { Firaun- bahwa Tuhannya adalah Allah } \\
\text { yang Maha segalanya". Shihab } \\
\text { menambahkan" "Allah Maha memberi }\end{array}$ \\
\hline
\end{tabular}

${ }^{37}$ M. Quraish Shihah, Tafsir Al-Misbah: Pesan, Kesan, dan Keserasian Al-Quran...h. 598-599

${ }^{38}$ Muhammad Thalib, Al-Quranul Karim: Tarjamah Tafsiriyah, (Solo: CV Qolam Mas, 2012) h. 246

39 Abdullah bin Muhammad bin Abdurrahman bin Ishaq Al-Sheikh (Peneliti/Pentahqiq). Tafsir Ibnu Katsir: Jilid 5... h. 387.

${ }^{40}$ M. Quraish Shihah, Tafsir Al-Misbah: Pesan, Kesan, dan Keserasian Al-Quran...h. 601. 


\begin{tabular}{|c|c|c|}
\hline & & $\begin{array}{l}\text { petunjuk sebagai bukti bahwa Dia berhak } \\
\text { dipertuhankan oleh segala sesuatu". }\end{array}$ \\
\hline 51. & $\begin{array}{l}\text { Firaun berkata: "Bagaimana dengan } \\
\text { keadaan umat-umat masa lalu?." }\end{array}$ & $\begin{array}{l}\text { Tindak tutur yang terdapat dalam dialog } \\
\text { ini adalah ilokusi jenis asertif berupa } \\
\text { "mengajukan pertanyaan". Korpus data } \\
\text { dalam ayat } 51 \text { memiliki makna "Firaun } \\
\text { melakukan investigasi terhadap Musa dan } \\
\text { Harun perihal umat terdahulu". Menurut } \\
\text { Shihab, }{ }^{41} \text { lafadz "Bâl" mengindikasikan } \\
\text { sesuatu yang penting. Hal tersebut } \\
\text { bermakna pertanyaan Firaun memiliki } \\
\text { tujuan khusus yaitu untuk melemahkan } \\
\text { argumentasi Musa }\end{array}$ \\
\hline 52. & $\begin{array}{l}\text { Musa berkata: "Pengetahuan tentang } \\
\text { itu ada pada catatan Tuhanku. } \\
\text { Tuhanku tidak keliru dan tidak pula } \\
\text { lupa dalam mencatat setiap } \\
\text { keadaan." }\end{array}$ & $\begin{array}{l}\text { Tindak tutur yang terdapat dalam dialog } \\
\text { ini adalah ilokusi jenis asertif berupa } \\
\text { "memberitahukan". Korpus data dalam } \\
\text { ayat } 52 \text { memiliki makna 'Musa menjawab } \\
\text { dengan lugas atas pertanyaan yang } \\
\text { diajukan oleh Firaun bahwa Allah adalah } \\
\text { Tuhan yang Maha Mengetahui segalanya'. } \\
\text { Menurut Thabathaba'i }{ }^{42} \text { jawaban Musa } \\
\text { tentang balasan umat terdahulu adalah } \\
\text { kiasan tentang pengetahuan Allah tentang } \\
\text { segala sesuatu amat rinci yang tidak akan } \\
\text { pernah berubah dan tidak akan hilang. }\end{array}$ \\
\hline 53. & $\begin{array}{l}\text { Tuhan yang telah menciptakan bumi } \\
\text { dengan permukaan datar bagi kalian, } \\
\text { dan menjadikan dapat berjalan di } \\
\text { atas bumi itudengan bermacam- } \\
\text { macam jalan. Tuhan yang } \\
\text { menurunkan hujan dari langit. } \\
\text { Kamipun menumbuhkan berbagai } \\
\text { macam tumbuhan yang berpasang- } \\
\text { pasangan. }\end{array}$ & $\begin{array}{l}\text { Tindak tutur yang terdapat dalam dialog } \\
\text { ini adalah ilokusi jenis asertif berupa } \\
\text { "memberitahukan". Korpus data dalam } \\
\text { ayat } 53 \text { memiliki makna 'Musa } \\
\text { memaparkan lebih lanjut atas pertanyaan } \\
\text { yang diajukan oleh Firaun- bahwa } \\
\text { Tuhannya adalah Allah yang Maha kuasa } \\
\text { dan } 43 \text { pengetahuan Allah serta } \\
\text { penciptaannya sangat sempurna'. }\end{array}$ \\
\hline 57. & $\begin{array}{l}\text { Firaun berkata: Wahai Musa, apakah } \\
\text { kamu datang kepada kami dengan } \\
\text { sihirmu itu untuk mengusir kami dari } \\
\text { negeri kami? }\end{array}$ & $\begin{array}{l}\text { Tindak tutur yang terdapat dalam dialog } \\
\text { ini adalah ilokusi jenis asertif berupa } \\
\text { "mengajukan pertanyaan". Korpus data } \\
\text { dalam ayat } 57 \text { memiliki makna "Firaun } \\
\text { melakukan investigasi terhadap Musa dan } \\
\text { Harun perihal motif kedatangannya". }\end{array}$ \\
\hline 58 & $\begin{array}{l}\text { Jika begitu, kami akan datangkan } \\
\text { penyihir yang sepadan dengan kamu. } \\
\text { Karena itu, tetapkan waktu tertentu } \\
\text { untuk pertemuan kami dan kamu }\end{array}$ & $\begin{array}{l}\text { Tindak tutur yang terdapat dalam dialog } \\
\text { ini adalah ilokusi jenis komisif berupa } \\
\text { "menawarkan". Korpus data dalam ayat } \\
58 \text { memiliki makna "Musa menerima }\end{array}$ \\
\hline
\end{tabular}

${ }^{41}$ M. Quraish Shihah, Tafsir Al-Misbah: Pesan, Kesan, dan Keserasian Al-Quran...h. 603.

${ }^{42}$ M. Quraish Shihah, Tafsir Al-Misbah: Pesan, Kesan, dan Keserasian Al-Quran...h. 603-604.

${ }^{43}$ M. Quraish Shihah, Tafsir Al-Misbah: Pesan, Kesan, dan Keserasian Al-Quran...h. 604. 


\begin{tabular}{|l|lr|l|l|}
\hline & $\begin{array}{l}\text { pada suatu tempat terbuka. Baik } \\
\text { kami maupun kamu tidak boleh } \\
\text { mengingkari waktu yang telah } \\
\text { ditetapkan itu." }\end{array}$ & $\begin{array}{l}\text { tantangan dari para tukang sihir; tukang } \\
\text { sihir dengan sihirnya dan Musa dengan } \\
\text { kekuatan mukjizatnya". }\end{array}$ \\
\hline 59. & $\begin{array}{l}\text { Firaun berkata: "Waktu yang } \\
\text { ditetapkan bagi kalian yaitu pada } \\
\text { hari raya dan orang-orang akan } \\
\text { dikumpulkan pada pagi hari." }\end{array}$ & $\begin{array}{l}\text { Tindak tutur yang terdapat dalam dialog } \\
\text { ini adalah ilokusi jenis asertif berupa } \\
\text { "memberitahukan". Korpus data dalam } \\
\text { ayat 59 memiliki makna "Firaun } \\
\text { merespon tawaran Musa untuk adu } \\
\text { kekuatan pada waktu yang sudah } \\
\text { ditentukan". Arti dari kata "dhuha" } \\
\text { 44adalah waktu sepenggalan siang. }\end{array}$ \\
\hline
\end{tabular}

\section{Dialog Nabi Musa as. dengan Para Tukang Sihir Firaun}

\begin{tabular}{|c|c|c|}
\hline Ayat & Al-Quran Tarjamah Tafsiriyah ${ }^{45}$ & Analisis \\
\hline 61. & $\begin{array}{l}\text { Musa berkata kepada ahli sihir-ahli } \\
\text { sihir Firaun: "Kalian akan celaka. } \\
\text { Janganlah kalian berdusta atas } \\
\text { nama agama. Karena kalian kelak } \\
\text { akan dihancurkan dengan adzab } \\
\text { Allah. Sungguh amat celaka orang } \\
\text { yang berdusta atas nama agama. }\end{array}$ & $\begin{array}{l}\text { Tindak tutur yang terdapat dalam dialog ini } \\
\text { adalah ilokusi jenis direktif berupa } \\
\text { "menasehati" dan jenis "komisif" } \\
\text { bersumpah. Korpus data dalam ayat } 61 \\
\text { memiliki makna "Musa menasehati tukang } \\
\text { sihir Firaun agar jangan berbohong atas } \\
\text { nama agama, sebab mereka akan celaka dan } \\
\text { binasa". Menurut ulama }{ }^{46} \text { kata berbohong } \\
\text { memiliki makna mengakui adanya sekutu } \\
\text { bagi Allah dan terdapat pengatur semesta } \\
\text { selain-Nya. }\end{array}$ \\
\hline 63. & $\begin{array}{l}\text { Ahli-ahli sihir Firaun berkata } \\
\text { sesama mereka: "Musa dan Harun } \\
\text { adalah dua orang laki-laki tukang } \\
\text { sihir. Dengan sihirnya, kedua orang } \\
\text { ini ingin mengusir kalian dari } \\
\text { negeri kalian dan menghancurkan } \\
\text { tradisi mulia kalian. }\end{array}$ & $\begin{array}{l}\text { Tindak tutur yang terdapat dalam dialog ini } \\
\text { adalah ilokusi jenis asertif berupa } \\
\text { "memberitahukan". Korpus data dalam ayat } \\
63 \text { memiliki makna "tukang sihir Firaun } \\
\text { melakukan perundingan untuk mengambil } \\
\text { kesepakatan". Shihab mengemukakan } \\
\text { kesepakatan yang dimaksud adalah mereka } \\
\text { meyakini bahwa Musa adalah benar utusan } \\
\text { Allah dan Musa memiliki keistimewaan. }\end{array}$ \\
\hline 64. & $\begin{array}{l}\text { Karena itu, semua tipu daya kalian } \\
\text { gabungkanlah menjadi satu, } \\
\text { kemudian kalian datang dengan } \\
\text { berbaris rapi menuju arena. } \\
\text { Sungguh pada hari ini siapa yang } \\
\text { menang akan jaya. }\end{array}$ & $\begin{array}{l}\text { Tindak tutur yang terdapat dalam dialog ini } \\
\text { adalah ilokusi jenis direktif berupa } \\
\text { "menyarankan". Korpus data dalam ayat } 64 \\
\text { memiliki makna tukang sihir Firaun saling } \\
\text { berkompromi untuk merapatkan barisan } \\
\text { dan menunjukkan kekuatan sihirnya di } \\
\text { hadapan Musa. }\end{array}$ \\
\hline 65. & Ahli-ahli sihir Firaun itu berkata: & Tindak tutur yang terdapat dalam dialog ini \\
\hline
\end{tabular}

${ }^{44}$ M. Quraish Shihah, Tafsir Al-Misbah: Pesan, Kesan, dan Keserasian Al-Quran...h. 613.

${ }^{45}$ Muhammad Thalib, Al-Quranul Karim: Tarjamah Tafsiriyah, (Solo: CV Qolam Mas, 2012) h. 252-253

${ }^{46}$ M. Quraish Shihah, Tafsir Al-Misbah: Pesan, Kesan, dan Keserasian Al-Quran...h. 615.

${ }^{47}$ M. Quraish Shihah, Tafsir Al-Misbah: Pesan, Kesan, dan Keserasian Al-Quran...h. 617. 


\begin{tabular}{|l|l|l|}
\hline $\begin{array}{l}\text { "Wahai Musa, apakah kamu yang } \\
\text { memulai mengeluarkan } \\
\text { kekuatanmu atau kami yang } \\
\text { terlebih dahulu mengeluarkan sihir? }\end{array}$ & $\begin{array}{l}\text { adalah ilokusi jenis "komisif" berupa } \\
\text { "menawarkan". Korpus data dalam ayat 65 } \\
\text { memiliki makna "tawaran tukang sihir } \\
\text { Firau agar Musa terlebih dahulu } \\
\text { mengeluarkan kekuatannya Menurut } \\
\text { Shihab, kesempatan pertama yang } \\
\text { diberikan oleh tukang sihir Firaun untuk } \\
\text { Musa sebagai bentuk rasa percaya diri dan } \\
\text { keyakinan akan kehebatan sihir yang } \\
\text { mereka miliki. }\end{array}$ \\
\hline 66. & $\begin{array}{l}\text { Musa berkata: "kalianlah yang } \\
\text { mengeluarkan sihir terlebih dulu." } \\
\text { Tiba-tiba tali-tali dan tongkat- } \\
\text { tongkat ahli sihir Firaun terlihat } \\
\text { oleh Musa bergerak-gerak bagaikan } \\
\text { ular. }\end{array}$ & $\begin{array}{l}\text { Tindak tutur yang terdapat dalam dialog ini } \\
\text { adalah ilokusi jenis deklaratif berupa } \\
\text { "menunjuk", dan jenis direktif berupa } \\
\text { "memerintah". Korpus data dalam ayat 66 } \\
\text { memiliki makna "Musa mempersilahkan } \\
\text { tukang sihir Firaun untuk mengeluarkan } \\
\text { shirnya". Shihab mencatat perintah Musa } \\
\text { terhadap tukang sihir Firaun bertujuan } \\
\text { untuk membuktikan bahwa mukjizat } \\
\text { kerasulan yang dimilikinya lebih kuat } \\
\text { daripada kekuatan sihir yang dimiliki oleh } \\
\text { mereka. }\end{array}$ \\
\hline
\end{tabular}

Dialog Nabi Musa as. dengan Bani Israil

\begin{tabular}{|c|c|c|}
\hline Ayat & Al-Quran Tarjamah Tafsiriyah ${ }^{50}$ & Analisis \\
\hline 85 & $\begin{array}{l}\text { Allah berfirman: "Wahai Musa, } \\
\text { sungguh kami telah menguji kaummu } \\
\text { selama kamu tinggal pergi, dan Samiri } \\
\text { telah menyesatkan mereka. }\end{array}$ & $\begin{array}{l}\text { Tindak tutur yang terdapat dalam } \\
\text { dialog ini adalah ilokusi jenis asertif } \\
\text { berupa "memberitahukan". Korpus data } \\
\text { dalam ayat } 85 \text { memiliki makna "Allah } \\
\text { menceritakan kepada Musa bahwa } \\
\text { Samiri adalah dalang kesesatan bagi } \\
\text { pengikutnya". }\end{array}$ \\
\hline 86 & $\begin{array}{l}\text { Musa pun kembali pada kaumnya } \\
\text { dengan rasa marah dan penuh rasa } \\
\text { sedih. Musa berkata: "Wahai kaumku, } \\
\text { bukankah Tuhan kalian telah } \\
\text { menjanjikan janji yang baik kepada } \\
\text { kalian? Apakah masa yang dijanjikan } \\
\text { kepada kalian itu kalian anggap lama, } \\
\text { ataukah memang kalian berkeinginan } \\
\text { ditimpa murka Tuhan kalian, sehingga }\end{array}$ & $\begin{array}{l}\text { Tindak tutur yang terdapat dalam } \\
\text { dialog ini adalah perlokusi. Korpus data } \\
\text { dalam ayat } 86 \text { memiliki makna "efek } \\
\text { informasi dari Allah pada ayat } \\
\text { sebelumnya membuat Musa marah dan } \\
\text { bersedih hati kepada pengikutnya. Kata } \\
\text { al-asf dalam ayat ini berarti benar-benar } \\
\text { marah. }{ }^{51} \text { Di sisi lain, }{ }^{52} \text { Musa sangat } \\
\text { menyayangkan perilaku sesat kaumnya }\end{array}$ \\
\hline
\end{tabular}

${ }^{48}$ M. Quraish Shihah, Tafsir Al-Misbah: Pesan, Kesan, dan Keserasian Al-Quran...h. 620.

${ }^{49}$ M. Quraish Shihah, Tafsir Al-Misbah: Pesan, Kesan, dan Keserasian Al-Quran...h. 620.

${ }^{50}$ Muhammad Thalib, Al-Quranul Karim: Tarjamah Tafsiriyah, (Solo: CV Qolam Mas, 2012) h. 253

${ }^{51}$ Abdullah bin Muhammad bin Abdurrahman bin Ishaq Al-Sheikh (Peneliti/Pentahqiq). Tafsir Ibnu Katsir: Jilid 5... h. 406

${ }^{52}$ M. Quraish Shihah, Tafsir Al-Misbah: Pesan, Kesan, dan Keserasian Al-Quran...h. 649-650. 


\begin{tabular}{|c|c|c|}
\hline & $\begin{array}{l}\text { kalian berani menyalahi janji } \\
\text { kepadaku? }\end{array}$ & $\begin{array}{l}\text { yang menyembah patung anak sapi } \\
\text { ketika Musa sedang tidak ada. }\end{array}$ \\
\hline 87 & $\begin{array}{l}\text { Mereka berkata: "Dalam melakukan } \\
\text { perbuatan kami ini, kami tidak } \\
\text { menyalahi janji kepadamu. Akan tetapi, } \\
\text { kami diberi barang-barang perhiasan } \\
\text { yang banyak oleh suatu kaum, lalu } \\
\text { kami lebur barang perhiasan itu dalam } \\
\text { api. Begitu pula Samiri meleburnya } \\
\text { dalam tungku api. }\end{array}$ & $\begin{array}{l}\text { Tindak tutur yang terdapat dalam } \\
\text { dialog ini adalah ilokusi jenis asertif } \\
\text { berupa "memberitahukan". Korpus data } \\
\text { dalam ayat } 87 \text { memiliki makna } \\
\text { "sanggahan pengikut Musa atas } \\
\text { tuduhan yang telah dilontarkannya". } \\
\text { Shihab menguatkan } 53 \text { dalam tafsirnya } \\
\text { bahwa pengikut Musa memohon maaf } \\
\text { dan menyesal atas kekeliruan yang } \\
\text { dilakukan oleh mereka selama ini } \\
\text { sembari menceritakan apa yang terjadi } \\
\text { kepada mereka saat Musa tidak ada. }\end{array}$ \\
\hline
\end{tabular}

Dialog Nabi Musa as. dengan Samiri

\begin{tabular}{|c|c|c|}
\hline Ayat & Al-Quran Tarjamah Tafsiriyah ${ }^{54}$ & Analisis \\
\hline 95 & $\begin{array}{l}\text { Musa berkata: 'Wahai Samiri, apa yang } \\
\text { mendorong kamu untuk berbuat sesat } \\
\text { semacam itu? }\end{array}$ & $\begin{array}{l}\text { Tindak tutur yang terdapat dalam } \\
\text { dialog ini adalah ilokusi jenis asertif } \\
\text { berupa "mengajukan pertanyaan". } \\
\text { Korpus data dalam ayat } 95 \text { memiliki } \\
\text { makna "Musa melakukan investigasi } \\
\text { terhadap Samiri, motif apa yang } \\
\text { melatarbelakangi kesesatan tersebut". } \\
\text { Shihab menguatkan dalam tafsirnya } 55 \\
\text { kata "Khathab" berfungsi untuk } \\
\text { memaparkan peristiwa besar yang } \\
\text { menjadi pusat perhatian dan bahan } \\
\text { pembicaraan umum. }\end{array}$ \\
\hline 96 & $\begin{array}{l}\text { Samiri berkata kepada Musa: "Aku } \\
\text { mengetahui sesuatu yang tidak mereka } \\
\text { ketahui. Aku telah mengambil } \\
\text { segenggam tanah bekas jejak malaikat } \\
\text { Jibril, lalu tanah itu aku gunakan } \\
\text { melebur perhiasan mereka dalam } \\
\text { tungku api. Karena hawa nafsuku } \\
\text { membisikkan begitu padaku. }\end{array}$ & $\begin{array}{l}\text { Tindak tutur yang terdapat dalam } \\
\text { dialog ini adalah ilokusi jenis asertif } \\
\text { berupa "memberitahukan" } \\
\text { "menyangkal". Korpus data dalam ayat } \\
96 \text { memiliki makna "Samiri merespon } \\
\text { dengan gamblang atas investigasi } \\
\text { Musa". Menurut Sayyid Qutub } \\
\text { perkataan Samiri dianggap sebagai } \\
\text { sangkalan saja untuk lari dari tanggung } \\
\text { jawab yang seharusnya ia pikul. }\end{array}$ \\
\hline 97 & $\begin{array}{l}\text { Musa berkata: "Wahai Samiri, pergilah } \\
\text { kamu! Kamu boleh bersenang-senang di } \\
\text { dunia dan bebas berkata: 'Biarkanlah } \\
\text { aku berbuat sesukaku', tetapi di akhirat } \\
\text { kelak kamu tidak akan dapat }\end{array}$ & $\begin{array}{l}\text { Tindak tutur yang terdapat dalam } \\
\text { dialog ini adalah ilokusi jenis direktif } \\
\text { berupa "memperingatkan". Korpus data } \\
\text { dalam ayat } 97 \text { memiliki makna "Musa } \\
\text { geram terhadap ulah Samiri dan }\end{array}$ \\
\hline
\end{tabular}

${ }^{53}$ M. Quraish Shihah, Tafsir Al-Misbah: Pesan, Kesan, dan Keserasian Al-Quran...h. 651.

${ }^{54}$ Muhammad Thalib, Al-Quranul Karim: Tarjamah Tafsiriyah, (Solo: CV Qolam Mas, 2012) h. 249

${ }^{55}$ M. Quraish Shihah, Tafsir Al-Misbah: Pesan, Kesan, dan Keserasian Al-Quran...h. 658.

${ }^{56}$ M. Quraish Shihah, Tafsir Al-Misbah: Pesan, Kesan, dan Keserasian Al-Quran...h. 660. 


\begin{tabular}{|l|l|l|}
\hline \multirow{1}{*}{$\begin{array}{l}\text { menghindarkan diri dari adzab Allah. } \\
\text { Pada saat itu, lihatlah tuhan kamu, } \\
\text { patung anak sapi yang selalu kamu } \\
\text { sembah di dunia itu. Sungguh patung } \\
\text { anak sapi yang kamu jadikan tuhan itu } \\
\text { akan kami bakar dan aku hanyutkan } \\
\text { abunya ke sungai." }\end{array}$} & $\begin{array}{l}\text { Sheringatkan akan balasan yang } \\
\text { Samiri diserang sebuah penyakit yang } \\
\text { berakibat dia dijauhi oleh orang-orang. }\end{array}$ \\
\hline $\begin{array}{l}\text { "Wahai bani Israil, Tuhan kalian yang } \\
\text { sebenarnya hanyalah Allah, tidak ada } \\
\text { Tuhan selain Dia. Ilmu-Nya meliputi } \\
\text { segala sesuatu. }\end{array}$ & $\begin{array}{l}\text { Tindak tutur yang terdapat dalam } \\
\text { dialog ini adalah ilokusi jenis asertif } \\
\text { berupa "menegaskan". Korpus data } \\
\text { dalam ayat 98 memiliki makna "Musa } \\
\text { memberitahuakan dan menegaskan } \\
\text { kepada pengikut-nya bahwa Allah } \\
\text { adalah Tuhan yang Maha Esa dan } \\
\text { Kuasa". Menurut Shihab ay ay ini } \\
\text { menyifati Allah dengan dua sifat } \\
\text { istimewa, yaitu sifat Esa dan } \\
\text { pengetahuan yang bersifat mutlak. }\end{array}$ \\
\hline
\end{tabular}

Mengacu pada hasil di atas, ditemukan beberapa tema umum yang sesuai dengan urutan konteks yang terdapat pada ST, di antaranya: 1) kisah Nabi Musa as. menerima wahyu pertama. 2) perintah Allah swt. kepada Nabi Musa as. dan permohonan Nabi Musa as. kepada Allah swt. 3) Nabi Musa as. dan Nabi Harun as. diperintahkan mendatangi Firaun, 4) Samiri berkhianat, 5) teguran Nabi Musa as. kepada Nabi Harun as., 6) Nabi Musa as. marah kepada Samiri.

Sesuai dengan urutan pengelompokan data di atas, penutur dan mitra tutur dapat diketahui dari masing-masing konteks. Ujaran pertama dimulai oleh Allah swt. sebagai Tuhan dan memiliki posisi paling tinggi, yang artinya Tuhan sebagai penutur, dengan kata lain berbicara langsung kepada mitra tutur yang dituju, yaitu Nabi Musa as.. Pada ayat 1116, Allah swt. memanggil Nabi Musa as. dan memerintahkan serta memberitahukan beberapa hal, sedangkan Nabi Musa as. di sini belum tampak akan responsnya. Pada ayat 1335, terjadi 'percakapan secara langsung' Allah swt. dengan Nabi Musa as., dan Allah swt. sebagai penutur dan Nabi Musa as. masih tetap menjadi mitra tutur yang merespons berupa melakukan apa saja yang diperintahkan oleh Allah swt.. Pada ayat-ayat selanjutnya, Nabi Musa as. banyak berperan sebagai penutur yang memulai percakapan terlebih dahulu. Mitra tutur Nabi Musa as. sesuai dengan urutan konteks di atas adalah keluarganya, Firaun, para tukang-tukang sihir, Bani Israil, Harun, dan Samiri, meskipun di sela-sela sebelum percakapan dengan Firaun dan Bani Israil, Allah swt. kembali menjadi penutur dan Nabi Musa as. menjadi mitra tutur.

Selain itu, kelima jenis tindak ilokusi ditemukan dari seluruh percakapan Nabi Musa as. tindak tutur ilokusi asertif yang ditemukan terdiri dari: menyatakan/memberikan informasi [2 korpus data], memberitahukan [17 korpus data], menegaskan [3 korpus data], memutuskan [1 korpus data], mengajukan pertanyaan [4 korpus data], menyangkal [1 korpus data], menyatakan [1 korpus data], dan mengingkari [1 korpus data], sedangkan tindak tutur ilokusi deklaratif yang ditemukan terdiri dari: menunjuk [2 korpus data], dan membebaskan

\footnotetext{
${ }^{57}$ M. Quraish Shihah, Tafsir Al-Misbah: Pesan, Kesan, dan Keserasian Al-Quran...h. 662.

${ }^{58}$ M. Quraish Shihah, Tafsir Al-Misbah: Pesan, Kesan, dan Keserasian Al-Quran...h. 662-663.
} 
[1 korpus data]. Tindak tutur ilokusi komisif yang ditemukan terdiri dari: sumpah [2 korpus data], menjanjikan [2 korpus data], memanjatkan doa [1 korpus data], dan menawarkan [2 korpus data], dan tindak tutur ilokusi direktif yang terdiri dari: menasehati [2 korpus data], memerintahkan [9 korpus data], meminta [1 korpus data], memperingatkan [1 korpus data], memberi pesan [2 korpus data], dan menyarankan [1 korpus data], serta yang terakhir tindak tutur ilokusi ekspresif yang terdiri dari: menyapa [1 korpus data], dan memanggil [1 korpus data].

Hal ini sesuai dengan Searle (dalam Rahardi ${ }^{59}$ ) bahwa tindak ilokusi asertif dapat dicontohkan seperti: menyatakan, membual, mengeluh, dan mengklaim. Leech menambahkan (dalam Tarigan ${ }^{60}$ ) bahwa ilokusi verba asertif dicontohkan seperti menegaskan, mengatakan, meramalkan, mengumumkan, menuntut. Sedangkan, tindak ilokusi direktif mencakup meminta, mengemis, menawar, memerintahkan, memerlukan, menasihati, memohonkan, dengan pola $\mathrm{S}+\mathrm{verba}+\mathrm{O}+$ kepada $+\mathrm{Y}$, seperti contoh pada ayat 58 'baik kami maupun kamu tidak boleh mengingkari waktu yang telah ditetapkan itu', yakni kami maupun kamu (kami=Firaun dan para penyihirnya, kamu=Nabi Musa as.) sebagai subjek, tidak boleh mengingkari yang dalam hal ini adalah kata kerja, dan disertai dengan objek=waktu yang telah ditetapkan. Di sini 'kepada $Y$ ' ditujukan kepada subjek itu sendiri.

Selain itu, tindak tutur ilokusi komisif yang ditemukan sesuai dengan Searle yang menyatakan bahwa komisif dicontohkan dengan janji, sumpah, kontrak, kesepakatan, dll. Begitu juga dengan tindak tutur ilokusi ekspresif, yang berupa salam, ucapan terima kasih, dll. pernyataan ini terbukti pada salah satu ayat, yaitu ayat 11 dan 17. Allah swt. memanggil Nabi Musa as. dan menyatakan Wahai, Musa, serta menanyakan tentang apa yang berada di tangan kanannya. Sedangkan, tindak tutur deklaratif berupa Nabi Musa as. yang ditunjuk oleh Allah swt. sebagai utusan pilihan.

\section{KESIMPULAN}

Berdasarkan analisis yang dilakukan, dapat dikemukakan beberapa intisari, yaitu (1) percakapan Nabi Musa as. dengan para mitra tuturnya merupakan jenis wacana lisan yang dituliskan, (2) menggunakan ragam bahasa tulis baku, (3) peserta yang terlibat dalam percakapan dengan jumlah dua penutur, antara lain: Nabi Musa as. dengan Allah swt., Nabi Musa as. dengan Samiri, Nabi Musa as. dengan Harun, dan Nabi Musa as. dengan Firaun. Sedangkan peserta yang terlibat dalam percakapan dengan jumlah penutur lebih dari dua, antara lain: Nabi Musa as. dengan keluarganya, Nabi Musa as. dengan para tukang sihir Firaun, dan Nabi Musa as. dengan Bani Israil, (4) topik yang dibicarakan adalah penyampaian risalah kepada Firaun tentang eksistensi Tuhan Yang Maha Esa dan seruan untuk memasuki agama Allah swt..

Selain itu, terkait dengan tindak tutur ilokusi dapat disimpulkan bahwa (1) terdapat temuan ilokusi asertif, yang terdiri dari: menyatakan/memberikan informasi, memberitahukan, menegaskan, memutuskan, mengajukan pertanyaan, menyangkal, menyatakan, dan mengingkari, (2) terdapat temuan ilokusi deklaratif, berupa menunjuk dan membebaskan, (3) terdapat temuan ilokusi komisif, yang terdiri dari: sumpah, menjanjikan, memanjatkan doa, dan menawarkan, (4) terdapat temuan ilokusi direktif, yang terdiri dari:

${ }^{59}$ R. Kunjana Rahardi, Pragmatik: Kesantunan Imperatif Bahasa Indonesia, (Jakarta: Erlangga, 2005), hal. 36

${ }^{60}$ Tarigan, Henry Guntur, Pengajaran Pragmatik, (Bandung: Penerbit Angkasa, 2009), hal. 107-108 
menasehati, memerintahkan, meminta, memperingatkan, memberi pesan, dan menyarankan, dan yang terakhir (5) terdapat temuan ilokusi ekspresif, yang terdiri dari: menyapa, dan memanggil.

\section{DAFTAR REFERENSI}

Ainin, Moh. 2010. Fenomena Pragmatik dalam al-Quran: Studi Kasus terhadap Pertanyaan. Malang: Misykat.

Al-Wāhidiy Imām Abī Al-Hasan 'Aliy bin Ahmad. 2016. Asbāb Nuz̄ūl Al-Qurān. Beirut: Dār Al-Kutub Al-Islāmiyyah.

Asrori, Imam. 1997. Analisis Wacana Humor Arab dalam Majalah Alharas Alwathany. Jurnal Bahasa, Sastra, Seni dan Pengajarannya: BAHASA DAN SENI, 25 no. 1: h. 2041.

Austin, J.L. 1962. How to Do Things with Words (London: Oxford University Press, Amen House)

Brown, Gillian, Yule, George. 1988. Discourse Analysis. Cambridge: The Press Syndicate of the University of Cambridge.

Bungin, Burhan. 2008. Analisis Data Penelitian Kualitatif. Jakarta: Raja Grafindo Persada.

Ishaq Al-Sheikh, Abdullah (Peneliti). 1994. Tafsir Ibnu Katsir: Jilid 5. Terjemahan Abdul Ghoffar, Abdurrahim Mu'thi. 2003. Bogor: Pustaka Imam Asy-Syafi'i.

Moleong, Lexy J. 2014. Metodologi Penelitian Kualitatif . Bandung: PT Remaja Rosda Karya Bandung.

Muhammad, Ibrahim. 2012. The Miracle of Seven: Akurasi Angka Matematis Al-Quran. Jakarta: Quanta.

Mukhlas, Moh. 2019. Fenomena Pragmatis dalam Al-Quran (Kajian atas Bentuk Imperatif pada Surat Al-Nur), Jurnal Al-Ta'dib Vol.9, No. 1, Juni.

Mustaqim, Muhammad Sirotol. 2014. Tinjauan Pragmatik Surat Al-Fatihah Terjemahan Indonesia Versi Departemen Agama. Skripsi: Universitas Negeri Yogyakarta.

Pratama, Oka Putra. 2017. Tindak Tutur Santun dalam Kisah NabiYusuf", Arabiyat: Jurnal Pendidikan Bahasa Arab dan Kebahasaaraban Vol.4, No,2, Desember .

Rahardi, Kunjana. 2005. Pragmatik: Kesantunan Imperatif Bahasa Indonesia. Jakarta: Erlangga.

Rofiq, Faiq Ainur. 2015. Analisa Redaksi Tindak Tutur Imperatif dalam Surat Al-Baqarah”, Jurnal Kodifikasia Vol. 9, No.1. 